\title{
PENGEMBANGAN BAHAN AJAR BAHASA ARAB BERBASIS KOMUNIKATIF UNTUK MAHASISWA PROGRAM STUDI KEPERAWATAN STIKES PURNA BHAKTI HUSADA BATUSANGKAR
}

\author{
Nurlaila \\ Program Studi Pendidikan Bahasa Arab Sekolah Tinggi Agama Islam Negeri Batusangkar \\ Korespondensi: Jl. Sawah Tabing No. 10 Rambatan Batusangkar, Sumatera Barat \\ e-mail: nur.laila304@gmail.com
}

\begin{abstract}
The aim of this study was to produce valid, practical and effective Arabic instructional materials for students majoring in nursing department of STIKES Purna Bhakti Husada Batusangkar. This study employed research and development design, especially IDI (instructional development institute) which consisted of three phase analysis: front-end analysis, prototype and assessment. The findings of the study showed that the instructional materials were valid both in terms of content and construct, practical and effective.
\end{abstract}

Kata kunci: bahan ajar, komunikatif, keperawatan, penelitian pengembangan

\section{PENDAHULUAN}

$\mathrm{P}$ erkembangan dan kemajuan peradaban menuntut bahasa Arab tidak hanya dibelajarkan untuk tujuan komunikasi sehari-hari tetapi juga untuk tujuan-tujuan tertentu, yang disebut dengan pembelajaran bahasa Arab untuk tujuan khusus (ta'lim al- 'Arabiyah li aghradh khashshah). Dalam perkembangannya, bermunculan berbagai program pembelajaran bahasa Arab untuk tujuan khusus ini, seperti pembelajaran bahasa Arab untuk tujuan akademis dan pembelajaran bahasa Arab profesi, seperti Bahasa Arab untuk pengacara, pengusaha, dokter, perawat, dan lainlain.

Sebagai program pendidikan yang betujuan menciptakan tenaga medis khususnya keperawatan, program D III dan S1 Keperawatan pada berbagai AKPER dan STIKES memiliki sejumlah mata kuliah yang menunjang profesi tersebut dengan merujuk pada pedoman kurikulum yang diterbitkan oleh Kementerian Kesehatan. Selain dibekali dengan ilmu keperawatan, mahasiswa juga dibekali dengan kemampuan berbahasa asing agar lulusannya siap ditempatkan dimana saja. Bahasa Arab merupakan salah satu mata kuliah bahasa asing yang dibelajarkan di program D III dan S1 Keperawatan di Sumatera Barat.

Pembelajaran bahasa Arab pada program pendidikan Keperawatan merupakan bagian dari program pembelajaran bahasa Arab untuk tujuan khusus, sehingga dalam memilih dan mendesain bahan ajar harus sesuai dengan tujuan yang diharapkan serta sesuai dengan kebutuhan dosen dan mahasiswanya. S. Nasution (198 2: 63) menjelaskan bahwa materi ajar dipilih berdasarkan tujuan 
yang hendak dicapai, dan sesuai dengan kebutuhan, minat dan bakat pembelajar. Selanjutnya, Tomlinson (1998: 96) menjelaskan bahwa pengembangan materi ajar bahasa mengacu pada kebutuhan pengajar dan pembelajar sebagai input bahasa dan sumber yang bermanfaat untuk memaksimalkan hasil belajar dengan cara-cara yang dirancang untuk mempromosikan materi ajar bahasa.

Berdasarkan observasi pendahuluan, peneliti menemukan bahwa pembelajaran bahasa Arab pada program pendidikan Keperawatan selama ini belum memiliki bahan ajar yang sesuai dengan kriteria yang dikemukakan di atas. Dalam pelaksanaannya, sebagian dosen hanya mengambilkan bahan ajar dari berbagai sumber, atau disusun sendiri sesuai dengan keinginan dosen tanpa melalui analisis kebutuhan. Praktek seperti ini menyebabkan pembelajaran bahasa Arab pada program pendidikan Keperawatan kurang berhasil guna, karena bahan ajar yang diberikan tidak sesuai dengan kebutuhan mereka, yaitu sebagai penunjang profesionalitasnya dalam menjalankan profesi sebagai tenaga medis.

Sahertian (2004:1) menyatakan hasil belajar seseorang ditentukan oleh berbagai faktor yang mempengaruhinya, salah satu faktor yang ada di luar individu adalah tersedianya bahan ajar yang memberi kemudahan bagi individu untuk mempelajarinya, sehingga menghasilkan belajar yang lebih baik. Sementara dalam pembelajaran bahasa Arab bagi mahasiswa Keperawatan belum tersedia bahan ajar seperti yang dikemukakan di atas. Oleh karena itu, peneliti ingin mengembangkan suatu bahan ajar bahasa Arab berbasis komunikatif untuk mahasiswa Keperawatan sebagai sebuah produk yang sesuai dengan kebutuhan mahasiswa, menggambarkan tujuan yang ingin dicapai, mengatasi kesulitan mahasiswa, dan dirancang untuk siap digunakan dalam proses pembelajaran.
Tujuan umum pengembangan ini adalah untuk menghasilkan bahan ajar bahasa Arab berbasis kominikatif untuk mahasiswa Keperawatan. Adapun tujuan khusus dari penelitian ini adalah untuk mengetahui bagaimana validitas, praktikalitas, dan efektifitas bahan ajar bahasa Arab berbasis komunikatif untuk mahasiswa Keperawatan

\section{KAJIAN TEORI}

\section{Pendekatan Komunikatif}

Pendekatan komunikatif merupakan pendekatan yang memandang bahasa lebih tepat dilihat sebagai sesuatu yang berkenaan dengan apa yang dapat dilakukan atau ditindakkan dengan bahasa tersebut (fungsi bahasa) atau berkenaan dengan makna apa yang dapat diungkapkan melalui bahasa (nosi), bukan berkenaan dengan butir-butir tata bahasa. Bahasa digunakan untuk meminta maaf, menyapa, membujuk, menasehati, memuji, atau untuk mengungkapkan makna tertentu, tidak untuk menjelaskan kategori-kategori gramatikal (Purwo, 1990: 50). Senada dengan pendapat di atas, Sumardi (1996: 12) menjelaskan bahwa pendekatan ini disusun atas dasar fungsi dan kebutuhan pembelajar, dengan harapan pembelajar dapat menggunakan bahasa untuk berkomunikasi dalam situasi yang sebenarnya dan bukan komunikasi yang dibuat-buat.

Konsep kemampuan komunikatif pertama kali dimunculkan sekitar 30-an tahun yang lalu oleh Dell Hymes (1972) seorang pakar sosiolinguistik, sebagai respon terhadap keterbatasan konsep kompetensi dan performansi model bahasa Chomsky (Richards dkk, 1992: 69). Pendekatan komunikatif ini pada dasarnya bertujuan untuk membentuk kompetensi komunikasi (communicative competence) pada pembelajar. Kompetensi komunikasi pada hakikatnya adalah pengetahuan mendalam dari seseorang 
tentang kapan seharusnya (when) atau tidak seharuanya (when not) berbicara, apa yang seharusnya dibicarakan (what), dengan siapa ia berbicara (with whom), kapan (when) atau dimana (where) pembicaraan itu terjadi, dan dengan cara apa pembicaraan itu seharusnya diungkapkan (manner) (Thu'aimah dkk, 2006: 47). Kridalaksana (1993: 30) mengemukakan bahwa kompetensi komunikatif adalah kemampuan bahasawan untuk mempergunakan bahasa yang secara sosial dapat diterima dan memadai

Pendekatan komunikatif tidaklah menafikan keberadaan struktur bahasa dalam pembelajaran secara total, namun pendekatan ini memberikan peran unsurunsur komunikatif yang lebih banyak dibanding unsur-unsur struktur dalam pembelajaran bahasa. Tarigan (1990: 6667) menjelaskan bahwa pendekatan ini berorientasi penuh pada fungsi bahasa sebagai alat komunikasi antar sesama. Untuk mengungkapkan berbagai ungkapan dalam aktifitas komunikasi yang riil, seseorang harus mengetahui sejumlah fungsi bahasa agar ia dapat mengungkapkan tuturan bahasa sesuai dengan siapa, kapan, dan bagaimana bertutur.

Fungsi-fungsi bahasa yang dimaksudkan dalam pendekatan komunikatif tidak lain tujuan pembelajarannya adalah untuk mengembangkan kompetensi komunikatif pembelajar, sehingga pembelajaran bahasa dengan pendekatan komunikatif dianggap lebih relevan dengan fungsi bahasa itu sendiri yakni untuk komunikasi antar sesama, dengan kata lain bahwa pengembangan pembelajaran bahasa dewasa ini seyogyanya diarahkan untuk kemampuan berbahasa pembelajar secara aktif.

Hal ini menujukkan bahwa pembelajaran harus berpusat kepada pembelajar, yakni proporsionalitas peran antara pembelajar dan guru akan lebih banyak peran aktifitas pembelajar dalam pembelajaran bahasa, oleh karena itu, pembelajar tidak lagi menunggu, me- nerima apalagi hanya menghafal kaidahkaidah bahasa yang diajarkan tanpa ekplorasi dan konstruksi dari pembelajar itu sendiri terhadap pengetahuan dan praktek berbahasa yang diajarkan (Richards dkk, 1992: 76-77) Namun semua itu harus didukung oleh materi ajar yang sesuai dengan pendekatan komunikatif, baik berupa teks (dialog dan bacaan bebas), tugas (bercerita tentang kehidupan sehari-hari pembelajar, menceritakan kembali hasil perjalanan ke suatu tempat dengan redaksi bahasa sendiri dan lain-lain) maupun otentik (koran, majalah, kartu identitas, rekaman suara maupun gambar dan lain-lain) (Effendy, 2005: 69-70).

Dalam pendekatan komunikatif yang menjadi acuan adalah kebutuhan pembelajar dan fungsi bahasa yang bertujuan agar pembelajar dapat berkomunikasi dalam situasi yang sebenarnya. Dengan sendirinya acuan pokok setiap unit pelajaran adalah fungsi bahasa dan bukan tata bahasa. Tata bahasa merupakan sarana untuk melaksanakan maksud komunikasi bukan sebagai tujuan pembelajaran. Sehingga dalam proses pembelajaran, peranan pembelajar lebih menonjol (Pateda, 1991: 86).

Untuk memperjelas pemahaman tentang pendekatan komunikatif ini, Nababan (70-71) mengemukakan sejumlah ciri yang melekat pada pendekatan komunikatif antara lain: 1) adanya aktifitas komunikasi yang sebenarnya (realistis); 2) adanya aktifitas komunikasi yang penuh kebermaknaan; 3) adanya silabus komunikatif yang disiapkan telah melalui analisis kebutuhan pembelajar; 4) adanya pembelajaran berpusat kepada pembelajar; 5) adanya peran guru sebagai fasilitator, penyuluh, penganalisis kebutuhan pembelajar dan manager kelompok; 6) peran materi pengajaran adalah untuk mendukung aktifitas komunikatif pembelajar yaitu materi yang berbasis teks (text based), berbasis tugas 
(task based), dan berbasis bahan otentik (realia).

Dalam pendekatan komunikatif, latihan-latihan dan aktifitas-aktifitas pembelajaran relatif tidak dibatasi, sepanjang latihan-latihan tersebut dapat membantu pembelajar mencapai tujuan komunikatif dan dapat melibatkan pembelajar dalam komunikasi, serta harus menggunakan prosos-proses komunikatif seperti sharing informasi, negosiasi dan interaksi (Richards dkk, 1992: 76). Aktifitas-aktifitas komunikatif bisa saja berbentuk lisan ataupun tulisan. Aktifitas lisan bisa berbentuk rapat kelas, debat, simulasi atau kaji pengalaman. Sedangkan aktifitas tulisan bisa berbentuk pengumuman, iklan atau jurnal.

Sehubungan dengan guru, maka dalam pendekatan komunkatif ini, tugasnya menjadi semakin berat, karena guru dituntut untuk tidak hanya menguasai satu ragam bahasa melainkan berbagai ragam bahasa sesuai dengan sifat komunikasi yang diperlukan. Di samping itu, guru juga harus memperhatikan aspek-aspek sosial budaya si pemakai bahasa (Subana: 63-64).

Dari paparan di atas, dapat disimpulkan bahwa hakikat pendekatan komunikatif dalam pembelajaran bahasa yaitu pendekatan yang memandang bahasa sebagai sebuah gejala sosial yang berfungsi sebagai alat komunikasi antar individu dalam masyarakat dengan berbagai konteks yang melingkupinya. Pendekatan ini menekankan pada fungsi dan makna sekaligus dalam berbahasa, dan bukan terfokus pada tata bahasa yang seringkali tidak terkait dengan makna yang mau diungkapkan. Pendekatan ini mengajarkan bagaimana seseorang memiliki kompetensi komunikatif agar bisa menggunakan bahasa sesuai dengan fungsinya sebagai alat komunikasi.

\section{Bahan Ajar}

Menurut Tyler (1949: 1) sistem pembelajaran terdiri dari empat unsur seperti yang tergambar dalam empat pertanyaan yang dikemukakannya, yaitu: (1) apa tujuan pembelajaran yang seharusnya berusaha diwujudkan?, (2) apa informasi-informasi dalam pembelajaran yang disajikan untuk mewujudkan tujuan tersebut?, (3) bagaimana menata informasi-informasi tersebut sehingga bisa sampai pada pembelejar?, dan (4) bagaimana mengetahui tercapai atau tidaknya tujuan pembelajaran?

Empat pertanyaan di atas mengandung empat unsur utama sistem pembelajaran, pertanyaan pertama berkenaan dengan harapan yang ingin diwujudkan dalam diri pembelajar setelah melalui proses pembelajaran (tujuan). Pertanyaan kedua berkenaan dengan substansi yang mesti diperoleh oleh pembelajar dalam rangka mencapai tujuan (materi). Pertanyaan ketiga berkaitan dengan keterampilan seorang guru dalam menata materi agar mudah dipahami oleh pembelajar (metode). Pertanyaan keempat menyangkut ukuran yang digunakan untuk mengetahui tercapai atau tidaknya tujuan (evaluasi).

M. Muzammil Basyîr dkk (1415 $\mathrm{H}$ : 22-25) menjelaskan tujuan adalah deskripsi obyektif tentang bentuk-bentuk perubahan yang diharapkan pada diri pembelajar setelah malalui pengalaman belajar. Materi adalah nilai-nilai pendidikan dan pengetahuan yang harus dikuasai oleh pembelajar sesuai dengan tujuan. Metode adalah cara-cara yang bisa menformulasikan materi ke dalam diri pembelajar guna mencapai tujuan. Evaluasi adalah proses menghimpun data guna memastikan terwujudnya tujuan yang telah dirumuskan.

Keempat unsur di atas (tujuan, materi, metode dan evaluasi) merupakan satu kesatuan dan saling mempengaruhi. Materi merupakan satu diantara beberapa unsur yang berperan dalam pembelajaran. Materi ajar tersebut dituangkan dalam berbagai bahan ajar. 
Bahan ajar adalah segala bentuk bahan yang digunakan untuk membantu guru atau instruktur dalam melaksanakan kegiatan belajar mengajar di kelas. Bahan yang dimaksud bisa berupa bahan tertulis maupun tidak. Bahan ajar bisa juga diartikan dengan seperangkat materi yang disusun secara sistematis baik tertulis maupun tidak sehingga tercipta suasana yang memungkinkan pembelajar untuk belajar. Bahan ajar berbeda dengan buku teks, karena buku teks merupakan sumber informasi yang disusun dengan struktur dan urutan berdasar bidang ilmu tertentu.

Bahan ajar memilki karakteristik sebagai berikut: (1) Menimbulkan minat baca, (2) Ditulis dan dirancang untuk pembelajar, (3) Menjelaskan tujuan instruksional, (4) Disusun berdasarkan pola belajar yang fleksibel, (5) Struktur berdasarkan kebutuhan siswa dan kompetensi akhir yang akan dicapai (6) Memberi kesempatan pada siswa untuk berlatih, (7) Mengakomodasi kesulitan siswa, (8) Memberikan rangkuman, (9) Gaya penulisan komunikatif dan semi formal, (10) Kepadatan berdasar kebutuhan siswa, (11) Dikemas untuk proses instruksional, (12) Mempunyai mekanisme untuk mengumpulkan umpan balik dari siswa, (13) Menjelaskan cara mempelajari bahan ajar.

\section{Bahasa Arab Profesi}

Pembelajaran Bahasa Arab bagi non-Arab terbagi pada dua kategori, yaitu pembelajaran Bahasa Arab untuk komunikasi dalam kehidupan seharihari, dan pembelajaran Bahasa Arab untuk tujuan-tujuan khusus (Thu'aimah dkk, 2006: 223). Keduanya memiliki persamaan dalam beberapa hal, yaitu:

1. Keduanya merupakan program pembelajaran Bahasa Arab bagi penutur non-Arab.

2. Kedua program ini memiliki standar dasar yang sama dalam hal tujuan pembelajaran bahasa yaitu agar pem- belajar mampu berkomunikasi dengan baik dalam bahasa Arab dengan penutur asli.

3. Kedua program ini memerlukan metodologi kerja, baik dalam mengidentifikasi keterampilan, tujuan umum dan tujuan khusus, persiapan materi ajar, evaluasi dan lain-lain.

Sedangkan perbedaan antara kedua program ini antara lain sebagai berikut:

1. Aspek kebutuhan

a. Bahasa arab untuk kehidupan sehari-hari memenuhi beragam kebutuhan. Program ini memenuhi kebutuhan pembelajar misalnya untuk berbicara dengan sesama, berbicara dengan guru, mengunjungi perpustakaan, mengikuti diskusi/seminar, berbelanja di pasar, mengirim surat, melamar pekerjaan dan lain-lain.

b. Bahasa Arab untuk tujuan khusus memenuhi kebutuhan yang spesifik, sesuai dengan kebutuhan mahasiswa, misalnya yang berhubungan dengan dunia kesehatan, ekonomi, politik, hukum, pasar modal dan lain-lain.

2. Aspek konten

a. Bahasa Arab untuk kehidupan sehari-hari mencakup semua hal yang berhubungan dengan kehidupan publik. Baik dari segi tema, fitur linguistik (kosakata, instalasi, teks), ataupun persepsi budaya.

b. Bahasa Arab untuk tujuan khusus memiliki konten terbatas yang terkait dengan spesialisasi, baik aspek kosa kata, struktur, istilah ataupun konteks.

3. Aspek tujuan

a. Bahasa Arab untuk kehidupan sehari-hari tidak memiliki tujuan spesifik, hanya sebatas kebutuhan bahasa untuk interaksi dalam kontak sosial.

b. Bahasa Arab untuk tujuan khusus memiliki situasi yang berbeda. Tujuan dirumuskan sesuai dengan 
kebutuhan bahasa yang telah diidentifikasi sebelumnya.

4. Aspek sasaran

a. Sasaran pembelajaran Bahasa Arab untuk kehidupan sehari-hari sangat heterogen. Kelas bisa saja diikuti orang-orang yang bekerja dalam pekerjaan yang berbeda dan orangorang dengan berbagai kepentingan dan kebutuhan.

b. Sasaran pembelajaran Bahasa Arab untuk tujuan khusus bersifat homogen, memiliki satu tujuan yang sama yang menyatukan diantara mereka.

5. Aspek kurikulum

a. Pengembangan kurikulum Bahasa Arab untuk kehidupan sehari-hari lebih sulit daripada yang lain. Semua keterampilan bahasa harus dipelajari, mendengarkan dan berbicara, membaca dan menulis, karena aspek komunikasi dan luas.

b. Pengembangan kurikulum Bahasa Arab untuk tujuan khusus relatif lebih mudah, karena sasaran yang homogen dan kebutuhan yang sama.

6. Aspek materi

a. Materi pembelajaran Bahasa Arab untuk kehidupan sehari-hari memuat topik-topik yang umum.

b. Pembelajaran Arab untuk tujuan khusus memilih teks-teks yang berhubungan langsung dengan kebutuhan pembelajar,

7. Aspek peran guru

a. Pembelajaran Bahasa Arab untuk kehidupan sehari-hari menjadikan guru sebagai pusat pembelajaran.

b. Dalam pembelajaran Bahasa Arab untuk tujuan khusus biasanya siswa bekerja dalam kelompok, bertukar peran dan tanya jawab. Metode belajar mandiri umum digunakan, sehingga pembelajaran berpusat pada pembelajar, bukan pada guru.
Menurut Hutchinson (1987: 19), pembelajaran bahasa untuk tujuan khusus (specific purposes) merupakan sebuah pendekatan pembelajaran bahasa yang keseluruhan unsur-unsurnya (tujuan, materi, metode dsb) mengacu kepada alasan yang melatarbelakangi pembelajar untuk belajar bahasa, diantaranya alasan profesi.

T. Dudley Evans \& M. St. John (1999: 5) menjelaskan beberapa karakteristik pembelajaran bahasa untuk tujuan khusus, yaitu:

1. Karakteristik utama pembelajaran bahasa untuk tujuan khusus

a. pembelajaran dirancang untuk tujuan tertentu bagi pembelajar

b. metode dan aktifitas pembelajaran ditentukan berdasarkan bidang tujuan tersebut

c. pembelajaran difokuskan kepada hal-hal yang berhubungan dengan bahasa (struktur, kosakata dan pola-pola), kemahiran berbahasa dan teknik retorika yang sesuai dengan bidang tersebut.

2. Karakteristik lain

a. program pembelajaran ini berhubungan dengan beberapa bidang tertentu

b. dalam beberapa pendekatan dan metode juga menggunakan pendekatan dan metode sebagaimana dalam pembelajaran bahasa biasanya

c. program ini biasanya dirancang untuk pembelajar dewasa, baik di institusi pendidikan maupun di lembaga-lembaga profesi

d. program ini dirancang dengan pola umum untuk pembelajar tingkat menengah atau tingkat mahir, karena sebagian besar program ini menuntut adanya pengetahuan dasar pembelajar, meskipun juga mungkin digunakan untuk pembelajar tingkat dasar. 
Keperawatan sebagai sebuah profesi didefinisikan sebagai suatu bentuk pelayanan profesional yang merupakan bagian integral dari pelayanan kesehatan didasarkan pada ilmu dan kiat keperawatan berbentuk pelayanan biopsikososio-spiritual yang komprehensif, ditujukan kepada individu, keluarga dan masyarakat, baik sakit maupun sehat yang mencakup seluruh proses kehidupan manusia. Oleh karena itu sifat pendidikan keperawatan juga menekankan pemahaman tentang keprofesian.

Berdasarkan uraian di atas dapat disimpulkan bahwa bahasa Arab untuk mahasiswa keperawatan merupakan suatu bentuk pembelajaran bahasa Arab untuk tujuan khusus sehingga pembelajarannya harus memberikan kontribusi untuk tujuan keprofesian.

\section{METODE PENELITIAN}

\section{Jenis, Rancangan, dan Prosedur Penelitian}

Penelitian ini tergolong research \& development ( $\mathrm{R} \& \mathrm{D})$. Dalam pengembangan bahan ajar bahasa Arab ini, peneliti menggunakan rancangan penelitian model IDI (Instructional Development Institute) yang menerapkan prinsipprinsip pendekatan sistem dengan tiga tahapan, yaitu penentuan (define), pengembangan (develop), dan evaluasi (evaluate). Ketiga tahapan tersebut dihubungkan dengan umpan balik (feedback) untuk mengadakan revisi. Sesuai dengan model pengembangan IDI ini, peneliti membuat rancangan langkahlangkah pengembangan terdiri dari 3 tahap, yaitu: (1) analisis muka-belakang (front-end analysis), (2) tahap prototipe (prototype), dan (3) tahap penilaian (assessment).

Tahap analisis muka-belakang dilakukan guna mendapatkan gambaran kondisi di lapangan, tahap ini disebut tahap analisis kebutuhan (needs assess- ment). Pada tahap ini dilakukan langkah berikut: (a) analisis silabus, (b) analisis bahan ajar Bahasa Arab, (c) reviu literatur, (d) interviu teman sejawat, (e) analisis karakteristik mahasiswa

Berdasarkan hasil analisis mukabelakang dirancang prototipe. Pembuatan prototipe ini dilaksanakan melalui 2 tahap yaitu, (1) tahap validasi meliputi validitas isi dan validitas konstruk yang dimulai dengan proses siklis analisis pendahuluan dan penilaian pakar (expert review) yang disertai dengan diskusi atau wawancara langsung mengenai perbaikan yang harus dilakukan pada prototipe, (2) tahap praktikalitas yaitu tingkat keterpakaian prototipe perangkat pembelajaran oleh dosen dan mahasiswa yang diketahui melalui eksperimen pengajaran menggunakan perangkat pembelajaran yang telah direvisi berdasarkan penilaian oleh validator atau hasil pada tahap pertama. Sedangkan tahap penilaian (assesment) bertujuan untuk mengevaluasi apakah prototipe (versi ujicoba) dapat digunakan sesuai dengan harapan dan efektif untuk meningkatkan kualitas pembelajaran.

Teknik pengumpulan data dalam penelitian ini adalah (1) kuisioner yang terdiri dari kuisioner untuk expert, dosen pengampu dan mahasiswa, (2) dokumentasi yaitu dokumen silabus dan daftar hasil belajar, (3) wawancara kepada expert, dosen dan mahasiswa, (4) tes untuk melihat hasil belajar, (5) checklist tentang aktivitas dan motivasi siswa. Dalam pegumpulan data, peneliti menggunakan instrumen kuesioner, dokumen, pedoman wawancara, soal-soal tes dan lembar cheklis.

Untuk kuesioner dianalisis secara kuantitatif dan kualitatif. Untuk data yang diperoleh dari wawancara dianalisis secara kualitatif dengan menyusun fakta-fakta hasil temuan di lapangan untuk dikembangkan menjadi proposisi dan prinsip-prinsip, sedangkan hasil tes dianalisis dengan statistik deskriptif 
untuk menghitung rata-rata, standar deviasi dan perhitungan persentase.

\section{HASIL PENELITIAN}

\section{Hasil Tahap Analisis Muka-Belakang}

Bahan ajar dirancang berdasarkan hasil analisis muka-belakang. Kegiatan ini dimulai dari analisis silabus, analisis bahan-bahan ajar Bahasa Arab khususnya untuk tujuan medis, riviu literatur, interviu teman sejawat dan analisis karakteristik mahasiswa keperawatan. Berikut ini diuraikan hasil analisis muka belakang, yaitu:

1. Hasil wawancara dengan teman sejawat

Berdasaarkan hasil wawancara dengan teman teman sejawat maka diperoleh data bahwa bahan ajar Bahasa Arab yang digunakan untuk mahasiswa Keperawatan selama ini belum sesuai dengan kebutuhan mahasiswa yaitu Bahasa Arab sebagai penunjang profesi keperawatan yang akan dijalaninya.

Oleh karena itu, melalui pengembangan bahan ajar berbasis komunikatif ini diharapkan tersusun bahan ajar yang berisikan topik-topik yang dekat dengan dunia keperawatan dan mengandung istilah-istilah yang terkait dengan dunia keperawatan. Sedangkan struktur-struktur kalimat yang penting disajikan secara aplikatif bukan teoritis, karena pada prinsipnya mahasiswa keperawatan dituntut untuk mampu berkomunikasi Bahasa Arab bukan mampu menguasai strukturnya.

2. Hasil analisis silabus mata kuliah

Prototipe bahan ajar berbasis komunikatif yang dirancang dan dikembangkan untuk tahap awal ini terdiri dari 5 dars yang disusun berdasarkan silabus yang ada. Masingmasing dars terdiri dari hiwar, mufradat, tarkib, tadribat 'ala al- hiwar, tadribat 'ala mufradat, tadribat 'ala al-tarkib, dan mulahazhah. Sedang qiraah dan kitabah tidak disajikan di setiap dars.

3. Hasil reviuw literatur bahan ajar

Bahan ajar adalah segala bentuk bahan yang digunakan untuk membantu guru, dosen atau instruktur dalam melaksanakan kegiatan belajar di kelas. Bahan ajar bisa juga diartikan dengan seperangkat materi yang disusun secara sistematis sehingga tercipta suasana yang memungkinkan pembelajar untuk belajar.

Bahan ajar ini disusun berdasarkan pendekatan komunikatif yaitu untuk mengembangkan kompetensi komunikatif pada pembelajar baik pada domain menyimak, berbicara, membaca, ataupun menulis. Dalam pendekatan komunikatif yang menjadi acuan adalah kebutuhan pembelajar dan fungsi bahasa yang bertujuan agar pembelajar dapat berkomunikasi dalam situasi yang sebenarnya. Dengan sendirinya acuan pokok setiap unit pelajaran adalah fungsi bahasa dan bukan tata bahasa. Tata bahasa merupakan sarana untuk melaksanakan maksud komunikasi bukan sebagai tujuan pembelajaran. Sehingga dalam proses pembelajaran, peran pembelajar lebih menonjol.

Bahan ajar yang disusun berdasarkan pendekatan komunikatif mengedepankan prinsip komunikasi, prinsip latihan, dan kebermaknaan. Sehingga pembelajaran dapat melibatkan pembelajar dalam penggunaan bahasa yang bermakna dan otentik

\section{Hasil Rancangan Bahan Ajar Berbasis Komunikatif}

Bahan ajar yang dirancang dan dikembangkan mengacu pada prinsipprinsip dalam pendekatan komunikatif. Berikut ini diuraikan karakteristik bahan 
ajar berbasis komunikatif yang telah dirancang.

1. Nomor setiap dars dibuat dalam kotak bershading yang didisain dengan warna dasar hijau dan warna huruf putih. Jenis huruf yang digunakan adalah traditional arabic dengan ukuran 20 dan ditebalkan.

2. Maudhu' dalam setiap dars didisain dengan warna merah tua. Jenis huruf yang digunakan adalah andalus dengan ukuran 26 dan ditebalkan.

3. Sub dars diberi penomoran angka yang didisain dalam lingkaran bershading dengan warna garis hitam, warna dasar kuning dan warna angka hitam dengan ukuran 18. Sub dars tersebut didisain dalam kotak bershading dengan fill effect dua warna yaitu sea green dan putih serta menggunakan style vertical. Jenis huruf yang digunakan adalah traditional arabic ukuran 20 dan ditebalkan.

4. Hiwar berisi percakapan antara dua mutakllim dengan karakter yang dekat dengan dunia keperawatan, seperti althabib, musa'id al-thabib, almumarridh, al-maridh, muwazhzhaf al-istiqbal dan lain-lain. Nama mutakallim didisain dalam kotak bershading dengan fill effect dua warna yaitu sea green dan putih serta menggunakan style vertical. Jenis huruf yang digunakan dalam hiwar ini adalah traditional arabic ukuran 20 yang diberi syakl guna memberikan kemudahan kepada mahasiswa dalam mempelajari materi. Kata kunci yang digunakan dalam hiwar ini adalah istami' wa a'id.

5. Mufradat berisi kosakata-kosakata baru yang ada dalam dars tersebut. Mufradat tersebut didisain dalam kotak bershading dengan fill effect dua warna yaitu hijau dan putih serta menggunakan style vertical. Jenis huruf yang digunakan traditional arabic ukuran 20 dan ditebalkan.
6. Tadribat berisi berbagai bentuk latihan yang terkait dengan materi dalam dars tersebut, baik tadribat yang berkaitan dengan hiwar, mufradat, ataupun tarkib. Tadribat yang dirancang terdiri dari beberapa bentuk, yaitu tahwil al-jumlah, ijra' alhiwar, wadh' 'alamah al-shahih aw al-khatha', washl bain al-kalimah wa al-shurah, ijabah al-sual, ikhtiyar alsual wa al-jawab musta'inan bi alshuwar dan lain-lain. Setiap tadribat selalu dimulai dengan memberikan pola atau contoh yang akan membantu mahasiswa dalam menyelesaikan tadribat tersebut yang disertai dengan pemberian warna merah pada setiap bagian yang menjadi penekanan dalam tadribat tersebut. Beberapa tadribat juga disajikan dengan bantuan gambar untuk memudahkan pemahaman dan menimbulkan kesan menarik bagi mahasiswa.

7. Mulahazhah berisi ulasan tentang tarkib yang terdapat dalam dars tersebut. Mulahazhah didisain dengan pemberian warna merah pada bagianbagian yang menjadi inti materi dalam mulahazhah tersebut.

\section{Validasi Bahan Ajar Berbasis Komunikatif}

Setelah bahan ajar ini selesai dirancang, kemudian dilakukan tahap validasi. Validasi bahan ajar ini dilakukan oleh 2 orang Validator. Rerata skor hasil validasi oleh validator adalah 3,36. Menurut kriteria hasil penilaian oleh ahli diperoleh bahwa bahan ajar berbasis komunikatif adalah sangat valid.

Di samping data di atas, Validator juga memberikan beberapa catatan diantaranya sebagai berikut:

1. Bahasa yang digunakan mengacu kepada bahasa formal, sehingga 'ibaratnya menjadi panjang.

2. Mufradat, tarkib dan tadribat disajikan secara berjenjang dan bertahap. 
3. Kata/kalimat diberi syakl sesuai kebutuhan sebagai bahasa komunikasi.

4. Gambar-gambar yang disajikan mempertimbangkan aspek tsaqafah Islamiyah.

5. Tadribat lebih bervariasi.

6. Di bagian akhir bahan ajar perlu ditulis daftar mufradat.

Berdasarkan komentar, saran dan catatan dari Validator, maka dilakukan revisi terhadap bahan ajar. Revisi tersebut meliputi aspek bahasa, konten, penyajian dan disain sesuai dengan saran dari Validator.

\section{Praktikalitas Bahan Ajar Berbasis Komunikatif}

Setelah proses validasi dengan pakar selesai, selanjutnya dilakukan revisi terhadap prototipe bahan ajar berbasis komunikaatif sesuai dengan saransaran Validator. Untuk melihat praktikalitas bahan ajar tersebut dilakukan uji coba di STIKES Purna Bhakti Husada Batusangkar.

Praktikalitas bahan ajar berbasis komunikatif diperoleh dari observasi pelaksanaan perkuliahan dan wawancara dengan mahasiswa. Observasi pelaksanaan perkuliahan difokuskan untuk melihat pelaksanaan perkuliahan dan melihat jika ada kendala dalam pelaksanaannya. Hasil observasi tersebut menunjukkan bahwa secara umum bahan ajar berbasis komunikatif sudah praktis. Dari aspek mahasiswa terlihat partisipasi yang cukup aktif ketika membahas tadribat. Sedangkan dari aspek waktu untuk pembelajaran materi dan pembahasan semua tadribat dalam satu dars terdapat satu kendala yaitu waktu yang tersedia tidak mencukupi karena tergantung kepada kemampuan dan kemahiran mahasiswa. Sebagai solusinya, dosen memberikan tugas kepada mahasiswa untuk menyelesaikannya di luar jam kuliah. Sedangkan wawancara di- lakukan setelah mahasiswa mengikuti pembelajaran Bahasa Arab menggunakan bahan ajar berbasis komunikatif. Hasil wawancara dengan mahasiswa tersebut menunjukkan bahwa menurut mahasiswa isi bahan ajar berbasis komunikatif ini sudah praktis. Indikatornya adalah konteks yang dibangun dalam materi dan tadribat yang sesuai. Bahan ajar berbasis komunikatif ini memiliki disain yang cukup menarik bagi mahasiswa. Namun, mahasiswa masih terkendala untuk menyelesaikan beberapa tadribat yang memiliki tingkat kesukaran yang tinggi. Oleh karena itu, bahan ajar berbasis komunikatif ini masih perlu direvisi terutama untuk beberapa tadribat.

\section{Efektifitas Bahan Ajar Berbasis Komunikatif}

Assesment dilakukan untuk mengetahui efektifitas bahan ajar berbasis komunikatif yang telah dirancang. Aspek efektifitas yang diamati dalam proses perkuliahan di kelas uji coba adalah aktivitas mahasiswa dan motivasi belajar mahasiswa. Hasil observasi menunjukkaan bahwa aktivitas mahasiswa selama kegiatan perkuliahan menggunakan bahan ajar berbasis komunikatif mengalami peningkatan dibandingkan sebelum menggunakannya. Aktifitas mahasiswa untuk berkomunikasi, menyelesaikan tadribat, bertanya dan berdiskusi menunjukkan peningkatan. Sedangkan hasil observasi tentang motivasi mahasiswa setelah mengikuti perkuliahan menggunakan bahan ajar berbasis komunikatif menunjukkan bahwa minat belajar mahasiswa serta minat menyelesaikan tadribat cukup tinggi. Kehadiran mahasiswa (95\%), mahasiswa mengaku senang mengikuti perkuliahan menggunakan bahan ajar tersebut. 


\section{PEMBAHASAN}

Kualitas hasil pengembangan dalam penelitian dapat ditentukan berdasarkan validitas, praktikalitas dan efektifitas. Validitas terlihat dari aspek ciri khas bahan ajar, kemampuan memotivasi, manfaat bagi mahasiswa, isi bahan ajar, bentuk tadribat, kesesuaian materi dan tujuan, pemilihan mufradat, kemasan dan lain-lain.

Berdasarkan hasil validasi bahan ajar dari Validator diketahui bahwa bahan ajar berbasis komunikatif yang telah dirancang sudah valid dengan beberapa perbaikan sesuai dengan catatan dan saran dari Validator. Artinya bahan ajar sudah berisi materi yang seharusnya diajarkan. Dengan demikian pertanyaan pertama dalam rumusan penelitian tentang validitas bahan ajar berbasis komunikatif sudah terjawab.

Sedangkan berdasarkan hasil observasi pelaksanaan perkuliahan menggunakan bahan ajar berbasis komunikatif dan hasil wawancara dengan mahasiswa diketahui bahwa bahan ajar berbasis komunikatif tersebut sudah praktis. Namun mahasiswa mengalami kendala ketika menyelesaikan tadribat yang memiliki tingkat kesukaran tinggi, serta kendala waktu yang kurang sehingga beberapa tadribat harus dikerjakan di luar jam kuliah sebagai tugas.

Efektifitas bahan ajar dilakukan setelah dipastikan bahwa produk tersebut valid dan praktis. Efektifitas bahan ajar berbasis komunikatif ini dilihat dari

\section{DAFTAR RUJUKAN}

Ahmad Fuad Effendi, 2005, Metodologi Pengajaran Bahasa Arab, Malang: Misykat

Bambang Kaswanti Purwo, 1990, Pragmatik dan Pengajaran Bahasa, Yogyakarta: Kanisius

Brian Tomlinson (ed), 1998, Material Development in Language Teach- aspek aktivitas dan motivasi belajar mahasiswa. Berdasarkan hasil obeservasi diketahui bahwa secara umum aktifitas mahasiswa meningkat dibandingkan sebelum menggunakan bahan ajar berbasis komunikatif, dan minat mahasiswa mengikuti perkuliahan cukup tinggi serta mereka lebih paham tentang materi. Dengan demikian dapat diketahui bahwa bahan ajar berbasis komunikatif yang dirancang sudah efektif

Ditinjau dari berbagai aspek, penelitian ini memiliki beberapa keterbatasan. Prototipe yang berhasil dirancang secara sempurna hanya terdiri dari 5 dars, hal ini terkendala oleh terbatasnya literatur yang berkaitan langsung dengan bahan ajar yang sedang dirancang. Di sisi lain tidak semua prototipe tersebut berhasil diujicobakan karena keterbatasan peneliti.

\section{KESIMPULAN DAN SARAN}

Bahan ajar yang dikembangkan mengacu pada prinsip-prinsip dalam pendekatan komunikatif yang dikemas dalam tampilan berwarna (shading dengan fill effect). Setiap dars terdiri dari hiwar, tadribat dan mulahazhah. Validasi bahan ajar dari Validator menunjukkan bahwa bahan ajar berbasis komunikatif yang dirancang sudah valid dengan beberapa perbaikan sesuai dengan catatan dan saran dari Validator. Bahan ajar berbasis komunikatif ini dapat dijadikan pedoman dalam pengembangan bahan ajar selanjutnya.

ing, Cambridge: Cambridge University Press

Harimurti Kridalaksana, Kamus Linguistik, Jakarta: PT Gramedia Pustaka Utama, 1993

Henry Guntur Tarigan, 1990, Pengajaran Kompetensi Komunikatif, Bandung: Angkasa 
Jack C Richard dan Theodore S. Rodgers, 1992, Approaches and Methods In Language Teaching, New York: Cambridge University Press

Mansoer Pateda, 1991, Linguistik Terapan, Flores: Nusa Indah, Cet. ke-1

Muhammad Muzammil Basyir dan Muhammad Malk Muhammad Sa'id, 1415 H, Madkhal ila alManahij wa Thuruq al-Tadris, Riyadh: Dar al-Liwa' li al-Nasyr wa al-Tauzi'

Mulyanto Sumardi, 1996, Berbagai Pendekatan dalam Pengajaran Bahasa dan Sastra, Jakarta: Indeks Pustaka Sinar Harapan, Cet. ke-2

komunikatif, 1, 146, 147, 148, 149, 152, $153,154,155,156$
Rusydi Ahmad Thu'aimah dan Mahmud Kamil al-Naqah, 2006, Ta'lim alLughah Ittishaliyan, Kairo: Esisko

R. W. Tayler, 1949, Basic Principles of Curriculum and Instruction, Chicago: University of Chicago Press

S. Nasution, 1992, Berbagai Pendekatan dalam Proses Belajar dan Mengajar, Jakarta: Bumi Aksara, Cet. ke-5

T. Dudley Evans \& M. St. John, 1999, Developments in English for Specific Purposes, Cambridge; Cambridge University Press

T. Hutchinson \& Waters, 1987, English for Specific Purposes, Cambridge: Cambridge University Press

pembelajaran, 1, 146, 147, 148, 149, $150,151,152,153,154$

pendidikan, 1, 146, 151 